\title{
Synthesis and Antimicrobial Activity of $\delta$-Viniferin Analogues and Isosteres
}

\author{
Luce Micaela Mattio ${ }^{1}{ }^{(}$, Cecilia Pinna ${ }^{1}$, Giorgia Catinella ${ }^{1}$, , Loana Musso ${ }^{1}{ }^{(0}$, Kasandra Juliet Pedersen ${ }^{2}$, \\ Karen Angeliki Krogfelt ${ }^{2}$, Sabrina Dallavalle ${ }^{1, *} \mathbb{*}$ and Andrea Pinto ${ }^{1[}$
}

1 Department of Food, Environmental and Nutritional Sciences (DeFENS), University of Milan, Via Celoria 2, 20133 Milan, Italy; luce.mattio@unimi.it (L.M.M.); cecilia.pinna@unimi.it (C.P.); giorgia.catinella@unimi.it (G.C.); loana.musso@unimi.it (L.M.); andrea.pinto@unimi.it (A.P.)

2 Institute of Molecular and Medical Biology, Roskilde University, 4000 Roskilde, Denmark; kjuliet@ruc.dk (K.J.P.); karenak@ruc.dk (K.A.K.)

* Correspondence: sabrina.dallavalle@unimi.it

Citation: Mattio, L.M.; Pinna, C.; Catinella, G.; Musso, L.; Pedersen, K.J.; Krogfelt, K.A.; Dallavalle, S.; Pinto, A. Synthesis and Antimicrobial Activity of $\delta$-Viniferin Analogues and Isosteres. Molecules 2021, 26, 7594 https://doi.org/10.3390/ molecules26247594

Academic Editor: Yuri Baukov

Received: 9 November 2021

Accepted: 12 December 2021

Published: 15 December 2021

Publisher's Note: MDPI stays neutral with regard to jurisdictional claims in published maps and institutional affiliations.

Copyright: (c) 2021 by the authors. Licensee MDPI, Basel, Switzerland. This article is an open access article distributed under the terms and conditions of the Creative Commons Attribution (CC BY) license (https:// creativecommons.org/licenses/by/ $4.0 /)$.
Abstract: The natural stilbenoid dehydro- $\delta$-viniferin, containing a benzofuran core, has been recently identified as a promising antimicrobial agent. To define the structural elements relevant to its activity, we modified the styryl moiety, appended at C5 of the benzofuran ring. In this paper, we report the construction of stilbenoid-derived 2,3-diaryl-5-substituted benzofurans, which allowed us to prepare a focused collection of dehydro- $\delta$-viniferin analogues. The antimicrobial activity of the synthesized compounds was evaluated against S. aureus ATCC29213. The simplified analogue 5,5'-(2-(4-hydroxyphenyl)benzofuran-3,5-diyl)bis(benzene-1,3-diol), obtained in three steps from 4-bromo-2-iodophenol (63\% overall yield), emerged as a promising candidate for further investigation ( $\mathrm{MIC}=4 \mu \mathrm{g} / \mathrm{mL})$.

Keywords: viniferin derivatives; stilbenoids; benzofuran nucleus; antimicrobials

\section{Introduction}

Resveratrol-derived natural products, belonging to the class of polyphenolic stilbenes, have increasingly attracted the attention of the scientific community because of their diverse biological activities and intriguing molecular architectures [1-3]. Nonetheless, the growing interest in the pharmacological potential of this class of molecules derives from the poor understanding of the in vivo mechanisms of action of their parent compound resveratrol, which severely limits its therapeutic use [4] and the necessity to increase its low bioavailability and in vivo stability. Over the last years, several efforts were made towards the synthesis of complex natural resveratrol oligomers, by biomimetic and de novo approaches [1,5-9]. However, only few research groups have focused on the synthesis of new resveratrol-derived chemical scaffolds with improved pharmacodynamics and pharmacokinetics with respect to the natural precursors [6,10-14]. In this scenario, we planned to set up a versatile and efficient synthetic strategy for the construction of dimeric resveratrol-derived benzofurans. Benzo[b]furan-containing molecules, present in numerous bioactive natural compounds, have been extensively studied because of their wide array of biological activities, including anticancer, antimicrobial, immunomodulatory, antioxidant, and anti-inflammatory properties [15-18]. It is noteworthy that, in the last years, the benzofuran motif has been revealed to be a pharmacophore of choice for the design of new antimicrobial agents $[19,20]$. We have recently reported the synthesis and the antimicrobial activity evaluation of a collection of resveratrol-derived monomers (i.e., resveratrol, pterostilbene, and piceatannol) and dimers (i.e., trans- $\delta$-viniferin, trans$\varepsilon$-viniferin, pallidol, dehydro- $\delta$-viniferin, and viniferifuran) against a series of foodborne pathogens [21]. 


\section{Results and Discussion}

Dehydro- $\delta$-viniferin $(\mathbf{1}$, Figure 1$)$, containing a benzofuran core, was identified as a promising compound against Gram-positive bacteria. In particular, it was shown to exert its antimicrobial activity on the foodborne pathogen Listeria monocytogenes Scott A, used as model of Gram-positive microorganisms (MIC and MBC values of 4.42 and $35.3 \mu \mathrm{M}$, respectively) [21]. The compound causes significant cytoplasmic membrane damage, by membrane depolarization, loss of membrane integrity, and severe morphological changes.

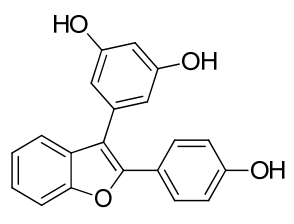

2

MIC $50.3 \mu \mathrm{M}$

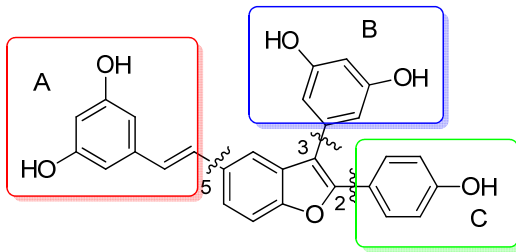

dehydro- $\delta$-viniferin (1)

MIC $4.42 \mu \mathrm{M}$<smiles>Oc1ccc(-c2cc3cc(/C=C/c4cc(O)cc(O)c4)ccc3o2)cc1</smiles>

3

MIC $743 \mu \mathrm{M}$<smiles>Oc1cc(O)cc(/C=C/c2ccc3occ(-c4cc(O)cc(O)c4)c3c2)c1</smiles>

4

MIC $44.5 \mu \mathrm{M}$

Figure 1. Structures and MIC values of model compounds 2, 3 and 4.

A previous SAR study performed by our group on simplified analogues of $\mathbf{1}$ (compounds $2,3,4)$ [22], which were obtained by the selective removal of the moieties linked in positions two, three, and five of the benzofuran core, showed that none of the structurally simplified compounds resulted to be more active than the precursor (Figure 1). In particular, a drastic drop of the antibacterial activity, due to the fatal lack of ring B, was observed for the derivative 3 (MIC value of $743 \mu \mathrm{M}$ against $4.42 \mu \mathrm{M}$ of dehydro- $\delta$-viniferin), thus suggesting the fundamental role of the aryl ring in position three of the benzofuran core. An important loss of antimicrobial activity, albeit to a lesser extent, was observed for compounds $\mathbf{2}$ and $\mathbf{4}$, obtained by the removal of the styryl group at position five and of the aryl ring in position two, respectively (MIC values of $50.3 \mu \mathrm{M}$ (2) and $44.5 \mu \mathrm{M}$ (4), vs. $4.42 \mu \mathrm{M}(\mathbf{1})$ ) (Figure 1).

Thus, we planned to prepare a novel set of dehydro- $\delta$-viniferin analogues and isosteres, obtained by modifying the styryl moiety A (Figure 1), while maintaining the unaltered rings $B$ and $C$. In particular, a removal of the double bond or its replacement with moieties such as an amide, alkyne or a saturated chain, could clarify the role of the geometry and stereoelectronic effects for the antimicrobial activity. In addition, we planned to synthesize dehydro- $\delta$-viniferin analogues that maintained the stilbene double bond, having, however, aromatic rings that were different from the resorcinol moiety.

In this perspective, we needed a versatile strategy to construct the 2,3-diaryl benzofuran ring bearing on $\mathrm{C}-5$ a proper functional group $(X)$ for the insertion of the appropriate fragment (Figure 2).

Among the various methods to access stilbenoid-derived 2,3-diaryl-5-substituted benzofurans [23-28], palladium catalysed reactions have proven to be rapid and convenient. In particular, an efficient one-pot method developed by Cacchi and coworkers [29] and successively implemented by Markina and coworkers [30], involves a Sonogashira coupling between an ortho-iodophenol and an aryl-substituted terminal alkyne to generate, at room temperature, the corresponding internal alkyne. The alkynylphenol obtained as an intermediate undergoes a simultaneous cyclization with the adjacent phenol group and an oxidative addition with the aryl-iodide-palladium complex with CuI, in acetonitrile at 
$100{ }^{\circ} \mathrm{C}$, under microwave irradiation. Using this approach, we obtained C5-substituted 2,3-diarylbenzofurans in a three-component one-pot reaction in $48-72 \%$ yields.

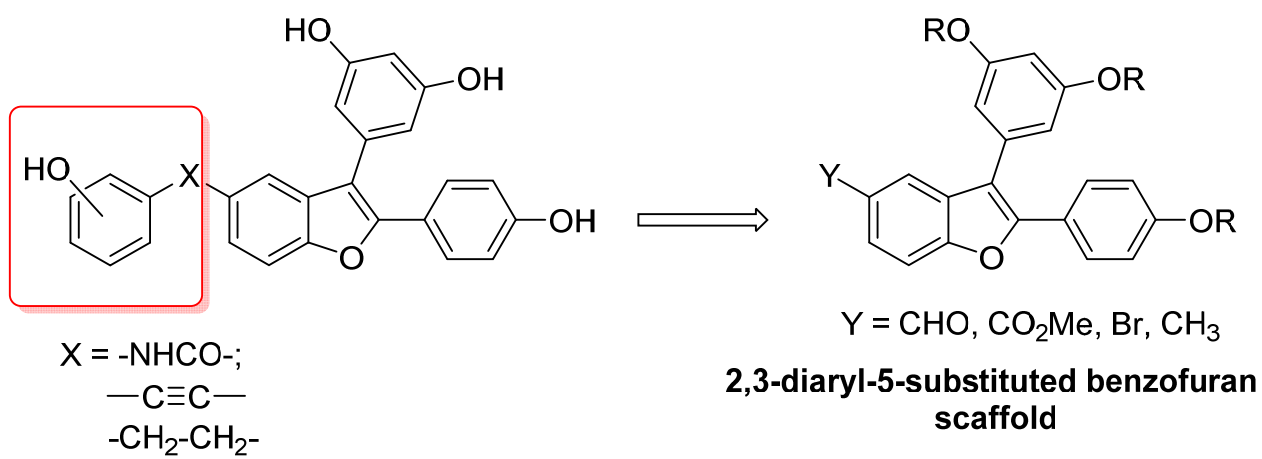

Figure 2. Retrosynthetic analysis for the obtainment of desired compounds.

Specifically, we generated the bromo functionalized intermediate 8 by reaction of 4-bromo-2-iodophenol 5, 4-ethynylanisole 6 and 3,5-dimethoxy-1-iodobenzene 7 (Scheme 1). Compound 8 underwent a Suzuki-coupling with (3,5-dimethoxyphenyl)boronic acid with $\mathrm{Pd}\left(\mathrm{PPh}_{3}\right)_{4}$ and aqueous $1 \mathrm{M} \mathrm{Cs}_{2} \mathrm{CO}_{3}$ in a mixture $\mathrm{DMF} / \mathrm{EtOH}$ (1:1), under microwave irradiation, for $20 \mathrm{~min}$ at $120{ }^{\circ} \mathrm{C}$ [30] to afford compound 9 in $91 \%$ yield. Final demethylation with $\mathrm{BBr}_{3}$ provided $\mathbf{1 0}$, as a simplified analogue of our hit compound $\mathbf{1}$, lacking the stilbene double bond.<smiles>Oc1ccc(Br)cc1I</smiles>

5<smiles>C#Cc1ccc(OC)cc1</smiles>

6<smiles>COc1cc(I)cc(OC)c1</smiles>

7<smiles>COc1ccc(-c2oc3ccc(Br)cc3c2-c2ccc(OC)cc2)cc1</smiles>

8<smiles>COc1ccc(-c2oc3ccc(-c4cc(OC)cc(OC)c4)cc3c2-c2cc(OC)cc(OC)c2)cc1</smiles>

9<smiles>Oc1ccc(-c2oc3ccc(-c4cc(O)cc(O)c4)cc3c2-c2ccc(O)cc2)cc1</smiles>

10

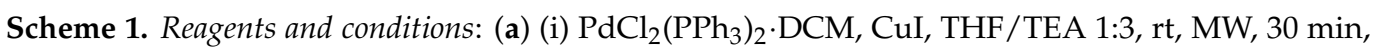
(ii) $\mathrm{ACN}, 100{ }^{\circ} \mathrm{C}, \mathrm{MW}, 25 \mathrm{~min}, 72 \%$; (b) (3,5-dimethoxyphenyl)boronic acid, $\mathrm{Pd}\left(\mathrm{PPh}_{3}\right)_{4}, \mathrm{DMF} / \mathrm{EtOH}$ 1:1, aq $1 \mathrm{M} \mathrm{Cs}_{\mathrm{s}} \mathrm{CO}_{3}, 120^{\circ} \mathrm{C}, 20 \mathrm{~min}, \mathrm{MW}, 91 \%$; (c) $\mathrm{BBr}_{3} 1 \mathrm{M} \mathrm{DCM}, \mathrm{DCM},-78{ }^{\circ} \mathrm{C}$ to rt, overnight, $96 \%$.

Then, we focused on the synthesis of the isosteres bearing an amide in place of the double bond. Amide isosteres of resveratrol have shown activity similar to the parent compound [31]. The amide linkage should allow to maintain the transoid architecture of the trans-stilbene, conferring however improved solubility and increased polarity $[32,33]$ as well as differences in electronic perturbations [32,33]. Therefore, analogue 15 was synthesized (Scheme 2). The Sonogashira/Cacchi type cyclization of the commercially available methyl 4-hydroxy-3-iodobenzoate 11, 4-ethynylanisole 6 and 3,5-dimethoxy-1iodobenze 7 gave the desired benzofuran 12 in 66\% yield. Hydrolysis of the ester 12 was performed with $\mathrm{LiOH} \cdot \mathrm{H}_{2} \mathrm{O}$ in a mixture of THF/water 1:1 for $24 \mathrm{~h}$. The resulting carboxylic acid 13 was reacted with 3,5-dimethoxyaniline, in presence of $\mathrm{EDC} \cdot \mathrm{HCl}$ and $\mathrm{HOBt}$, to give amide 14, which was demethylated with $\mathrm{BBr}_{3}$ to afford compound 15 in $73 \%$ yield. 
<smiles>C#Cc1ccc(OC)cc1</smiles><smiles>COc1ccc(-c2oc3ccc(C(=O)O)cc3c2-c2cc(OC)cc(OC)c2)cc1</smiles><smiles>COc1ccc(-c2oc3ccc(C(=O)Nc4cc(OC)cc(OC)c4)cc3c2-c2ccc(C)cc2)cc1</smiles>

13<smiles>O=C(Nc1cc(O)cc(O)c1)c1ccc2oc(-c3ccc(O)cc3)c(-c3cc(O)cc(O)c3)c2c1</smiles>

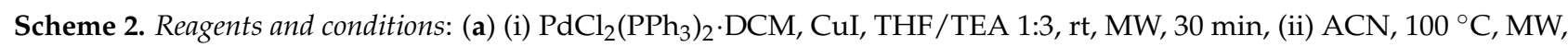
$25 \mathrm{~min}, 66 \%$; (b) $\mathrm{LiOH} \cdot \mathrm{H}_{2} \mathrm{O}, \mathrm{THF} / \mathrm{H}_{2} \mathrm{O}$ 1:1, rt, $24 \mathrm{~h}$, quantitative yield; (c) (i) EDC. $\mathrm{HCl}, \mathrm{HOBt}, \mathrm{DMF} ; 0{ }^{\circ} \mathrm{C}$ to rt, $90 \mathrm{~min}$, (ii) 3,5-dimethoxyaniline, DIPEA, DMF, $0{ }^{\circ} \mathrm{C}$ to rt, overnight, $70 \%$; (d) $\mathrm{BBr}_{3} 1 \mathrm{M} \mathrm{DCM}, \mathrm{DCM},-78{ }^{\circ} \mathrm{C}$ to rt, overnight, $73 \%$.

The ester 12 was envisaged as a versatile intermediate for the preparation of a set of dehydro- $\delta$-viniferin derivatives, differently substituted on ring A (Scheme 3 ). Reduction with $\mathrm{LiAlH}_{4}$ gave, quantitatively, compound 16, which was converted into the corresponding bromide derivative with $\mathrm{PBr}_{3}$. Reaction with triethyl phosphite at $130{ }^{\circ} \mathrm{C}$ overnight, which afforded the phosphonate 17 in $80 \%$ yield over two steps. The HWE reaction with 4-methoxybenzaldehyde provided the desired stilbene 18 , only as a trans isomer, in $86 \%$ yield. Unfortunately, attempts to deprotect the methyl groups with $\mathrm{BBr}_{3}$ at $-78{ }^{\circ} \mathrm{C}$ in dry $\mathrm{DCM}$, following the usual procedure, gave only degradation products.

Several troublesome efforts in the demethylation process confirmed that this step is an Achilles' heel in the synthesis of stilbenoids-derived compounds $[6,10,14,22]$.

Methyl groups are convenient protecting groups for phenolic moieties because of the availability of their starting reagents and their high stability to a wide variety of reaction conditions. However, as a not-negligible drawback, their high robustness requires harsh conditions in the deprotection step, often resulting in poor yields and product degradation in the presence of highly reactive double bonds $[5,6,10,22]$.

As stilbenoids are known to form dimers and polymers with a variety of acids, including $\mathrm{BBr}_{3}[34,35]$, alternative protocols were investigated. We first attempted to obtain the desired compound 19 by the initial deprotection of bromoderivative 8 , followed by a direct insertion of the $p$-hydroxystyryl moiety via the Heck reaction. However, the reaction gave a mixture of 19 and its isomer 20, coeluted in column chromatography (Scheme 3).

In another synthetic route, 2-iodo-4-methylphenol 22, prepared in excellent yields from para-cresol (21) with $\mathrm{N}$-iodosuccinimide and para-toluenesulfonic acid in acetonitrile [36], was used as the starting material (Scheme 4). In the one-pot-Sonogashira-Cacchi reaction conditions, the obtained intermediate gave the desired benzofuran derivative 23 in $48 \%$ yield. Intermediate $\mathbf{2 3}$ was smoothly demethylated to afford compound $\mathbf{2 4}$ in $90 \%$ yield. The protection of hydroxy groups with tert-butyldimethylsilylchloride and imidazole was performed in 1,2-dichloroethane at $60^{\circ} \mathrm{C}$, to give compound 25 in a good yield (86\%) [8]. Then, a radical bromination of the methyl group with NBS and AIBN as a radical initiator at reflux in $\mathrm{CCl}_{4}$ gave a brominated intermediate, which was converted into the corresponding 
phosphonate $\mathbf{2 6}$ with triethyl phosphite at $130{ }^{\circ} \mathrm{C}$ ( $84 \%$ yield). The intermediate $\mathbf{2 6}$ was reacted with the properly protected 3,4-bis((tert-butyldimethylsilyl)oxy)benzaldehyde in presence of LDA in THF in $16 \%$ yield. The use of $\mathrm{NaH}$ increased the yield to $52 \%$. Eventually, the deprotection of silyl groups was performed with tetrabutylammonium fluoride (TBAF) at $0{ }^{\circ} \mathrm{C}$ in THF, to afford compound 28 with a catechol on the styryl moiety (60\% yield).
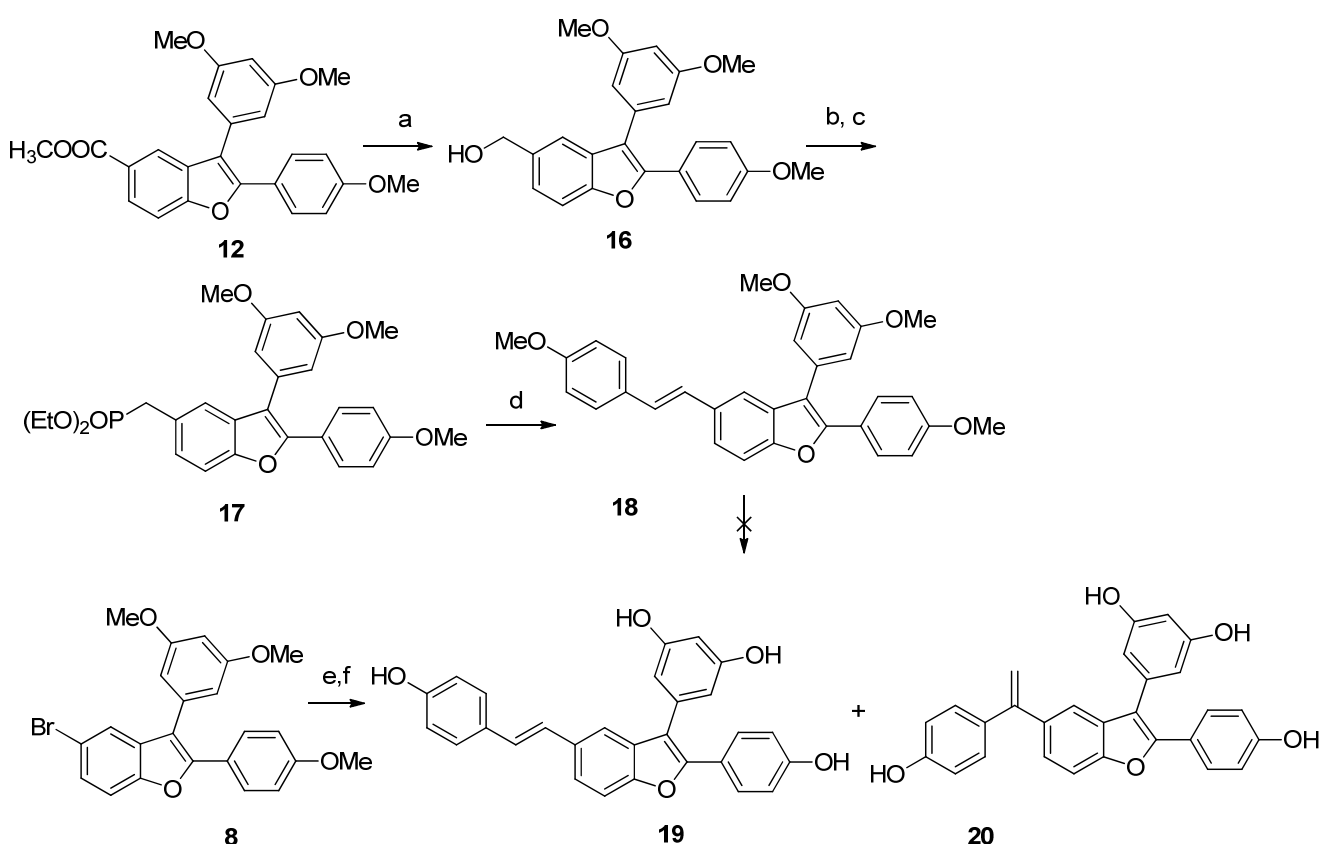

Scheme 3. Reagents and conditions: (a) $\mathrm{LiAlH}_{4}, \mathrm{THF}, 0{ }^{\circ} \mathrm{C}, 20 \mathrm{~min}$, quantitative yield; (b) $\mathrm{PBr}_{3}$, cat pyridine, $\mathrm{Et}_{2} \mathrm{O}$, rt to reflux, $2 \mathrm{~h}$, (c) $\mathrm{P}(\mathrm{OEt})_{3}, 130{ }^{\circ} \mathrm{C}$, overnight, $80 \%$ over two steps; (d) 4-methoxybenzaldehyde, $\mathrm{NaH}, 120^{\circ} \mathrm{C}, 30 \mathrm{~min}, \mathrm{MW}, 86 \%$; (e) $\mathrm{BBr}_{3} 1 \mathrm{M} \mathrm{DCM}, \mathrm{DCM},-78{ }^{\circ} \mathrm{C}$ to rt, overnight, $87 \%$; (f) 4-hydroxystirene, TEA, dppp (1,3-bis(diphenylphosphino)propane), $\mathrm{Pd}(\mathrm{OAc})_{2}$, dry DMF, $120^{\circ} \mathrm{C}, 48 \mathrm{~h}$.
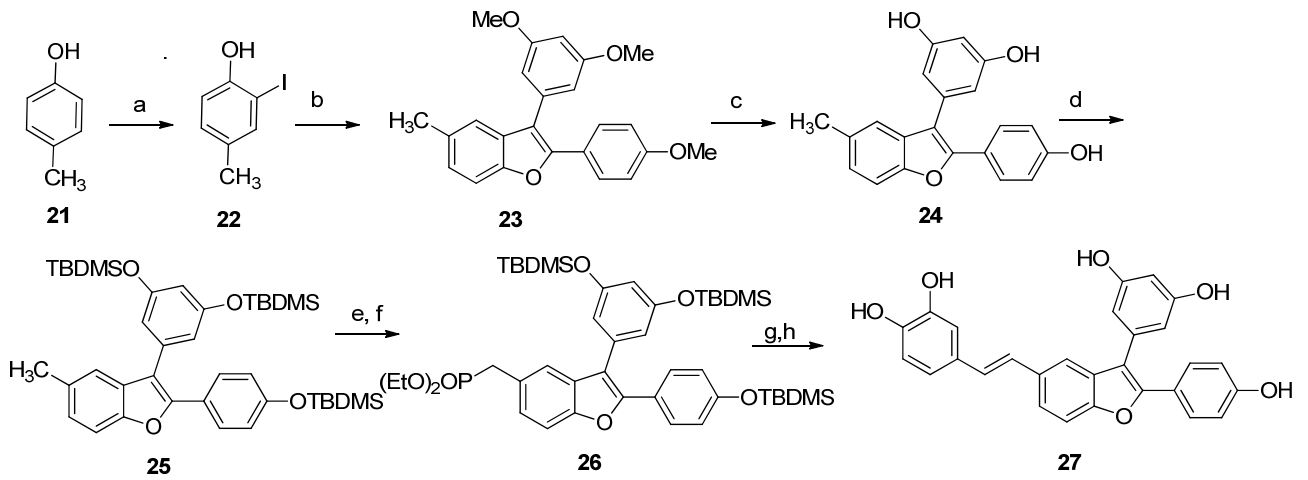

Scheme 4. Reagents and conditions: (a) (i) $\mathrm{p}-\mathrm{TsOH} \cdot \mathrm{H}_{2} \mathrm{O}, \mathrm{ACN}, \mathrm{rt}, 10 \mathrm{~min}$; (ii) NIS, rt, overnight, 97\%; (b) (i) 4-ethynianisole, $\mathrm{PdCl}_{2}\left(\mathrm{PPh}_{3}\right)_{2} \cdot \mathrm{DCM}, \mathrm{CuI}$, THF/TEA 1:3, rt, MW, 30 min, (ii) 3,5-dimethoxy-1iodobenzene, $\mathrm{ACN}, 100{ }^{\circ} \mathrm{C}, \mathrm{MW}, 25 \mathrm{~min}, 48 \%$; (c) $\mathrm{BBr}_{3} 1 \mathrm{M} \mathrm{DCM}, \mathrm{DCM},-78{ }^{\circ} \mathrm{C}$ to rt, overnight, $90 \%$; (d) TBDMSCl, imidazole, DCE, $60{ }^{\circ} \mathrm{C}, 8 \mathrm{~h}, 86 \%$; (e) NBS, AIBN, $\mathrm{CCl}_{4}$, reflux, 8 h, 37\%; (f) P(OEt) 3 , $130{ }^{\circ} \mathrm{C}$, overnight, $84 \%$; (g) 4-bis((tert-butyldimethylsilyl)oxy)benzaldehyde, $\mathrm{NaH}, \mathrm{THF}, 0{ }^{\circ} \mathrm{C}$ to rt, $24 \mathrm{~h}, 52 \%$; (h) TBAF, THF, $0{ }^{\circ} \mathrm{C}$ to rt, $2 \mathrm{~h}, 60 \%$.

The protection of phenol groups as t-butyldimethylsilylethers was applied also to the synthesis of the alkyne derivative 32 (Scheme 5). The high-yield demethylation of brominated intermediate 8 was thus followed by protection of the hydroxy groups as tert-butyldimethylsilyl ethers (28). 


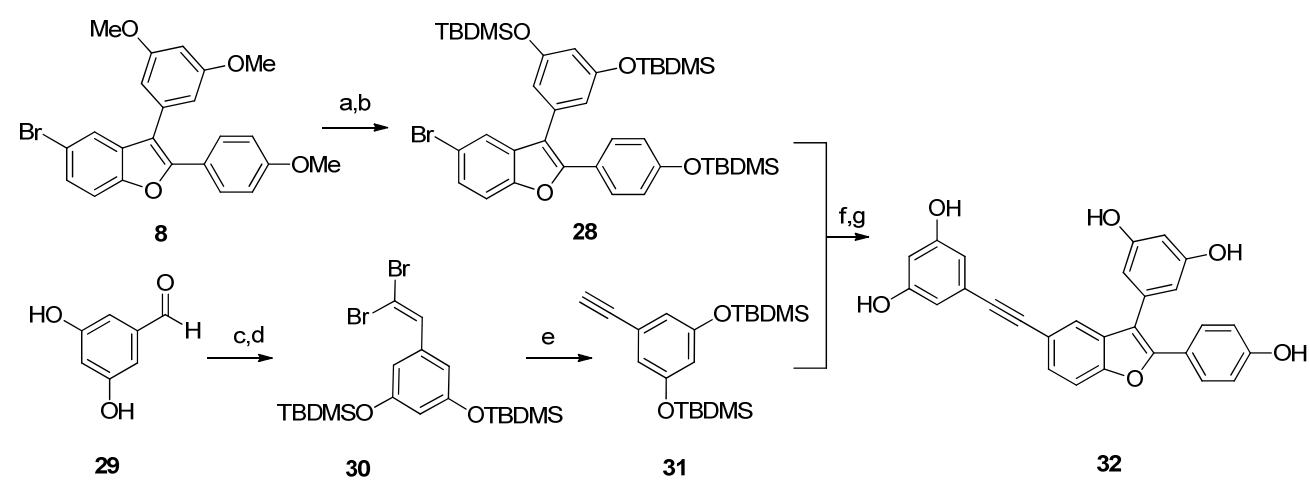

Scheme 5. Reagents and conditions: (a) $\mathrm{BBr}_{3} 1 \mathrm{M} \mathrm{DCM}$, dry $\mathrm{DCM},-78{ }^{\circ} \mathrm{C}$ to $\mathrm{rt}$, overnight, $87 \%$; (b) TBDMSCl, imidazole, DMF, $0{ }^{\circ} \mathrm{C}$ to rt, overnight, 81\%; (c) TBDMSCl, imidazole, $\mathrm{DMF}, 0{ }^{\circ} \mathrm{C}$ to rt, overnight, $74 \%$; (d) $\mathrm{CBr}_{4}, \mathrm{PPh}_{3}, \mathrm{DCM}, 0{ }^{\circ} \mathrm{C}$ to $\mathrm{rt}, 1 \mathrm{~h}, 83 \%$, (e) LDA, THF, $-78{ }^{\circ} \mathrm{C}, 1 \mathrm{~h}, 91 \%$; (f) $\mathrm{Pd}\left(\mathrm{PPh}_{3}\right)_{4}, \mathrm{CuI}, \mathrm{TEA}, 90^{\circ} \mathrm{C}, 8 \mathrm{~h}$; (g) KF, MeOH/THF, rt, overnight, $38 \%$ over 2 steps.

The alkyne 31 was obtained starting from 3,5-dihydroxybenzaldehyde 29, which was properly protected and then subjected to Corey-Fuchs conditions [37] to give the terminal dibromoalkene 30, which underwent lithium-halogen exchange and $\alpha$-elimination with LDA to afford 31 in excellent yield.

The final Sonogashira coupling was performed with $\mathrm{Pd}\left(\mathrm{PPh}_{3}\right)_{4}$ and $\mathrm{CuI}$ in triethylamine at reflux for $8 \mathrm{~h}$. The crude compound obtained was directly deprotected with KF to give the desired alkyne 32 in $38 \%$ yield, over two steps.

Finally, compound 33, having a saturated chain in place of the stilbene double bond, was obtained in a quantitative yield by the hydrogenation of dehydro- $\delta$-viniferin 1 with $\mathrm{Pd} / \mathrm{C}$ in ethanol at room temperature for $3 \mathrm{~h}$ (Scheme 6). Hydrogenation of $\delta$-viniferin 34, applying the same protocol, led to a dihydrobenzofuran ring cleavage (compound 35) [38].<smiles>Oc1ccc(-c2cc(O)ccc2-c2oc3ccc(/C=C/c4cc(O)cc(O)c4)cc3c2-c2ccc(O)cc2-c2ccc(CCc3cc(O)cc(O)c3)c(-c3cc(O)cc(O)c3)c2)cc1</smiles><smiles>CC(C)(C)C1Oc2ccc(O)cc2C1c1ccc(O)cc1C1Oc2ccc(/C=C/c3cc(O)cc(O)c3)cc2C1c1ccc(O)cc1</smiles>

Scheme 6. Reagents and conditions: (a) $\mathrm{H}_{2} / \mathrm{Pd} / \mathrm{C} 10 \% \mathrm{wt}, \mathrm{EtOH}, \mathrm{rt}, 4 \mathrm{~h}$, quantitative yield.

The model compound 1 and the novel derivatives 10, 15, 27, 32, 33, and 35 were tested against $S$. aureus ATCC29213, and the minimum inhibition concentration (MIC) and minimal bactericidal concentration $(\mathrm{MBC})$ were determined. The concentration range was $0.25-512 \mu \mathrm{g} / \mathrm{mL}$ for the synthesized compounds and $0.5-64 \mu \mathrm{g} / \mathrm{mL}$ for the reference compound tobramycin. The results are reported in Table 1. The MIC was evaluated using two different growth media: Mueller Hilton Broth, cation adjusted (MHB-II 212322, Becton Dickinson and Company, 7 Loveton Circle Spark, MD, USA), and Tryptic Soy Broth (22092-500 G, MERCK, Vandtårnsvej 62A, 5 sal. Søborg, Denmark). 
Table 1. Susceptibility testing of $S$. aureus towards model compound $\mathbf{1}$ and newly synthesized analogues.

\begin{tabular}{|c|c|c|c|c|c|}
\hline \multirow[b]{3}{*}{ Compounds } & \multirow[b]{3}{*}{ Structure } & \multicolumn{4}{|c|}{ S. aureus ATCC29213 } \\
\hline & & \multicolumn{2}{|c|}{ MHB-II } & \multicolumn{2}{|c|}{ TSB } \\
\hline & & $\begin{array}{c}\mathrm{MIC} \\
(\mu \mathrm{g} / \mathrm{mL})\end{array}$ & $\begin{array}{c}\text { MBC } \\
(\mu \mathrm{g} / \mathrm{mL})\end{array}$ & $\begin{array}{c}\text { MIC } \\
(\mu \mathrm{g} / \mathrm{mL})\end{array}$ & $\begin{array}{c}\mathrm{MBC} \\
(\mu \mathrm{g} / \mathrm{mL})\end{array}$ \\
\hline 1 & & $2 *$ & $\geq 512$ & $\geq 512$ & $\geq 512$ \\
\hline 10 & & $4^{*}$ & $\geq 512$ & $32 *$ & $\geq 512$ \\
\hline 15 & & $16^{*}$ & $\geq 512$ & $32 *$ & $\geq 512$ \\
\hline 27 & & $16^{*}$ & $\geq 512$ & $16^{*}$ & $16^{*}$ \\
\hline 32 & & $2 *$ & 8 & $2 *$ & $2 *$ \\
\hline 33 & & $4^{*}$ & 4 & $4^{*}$ & $4^{*}$ \\
\hline 35 & & 256 & $\geq 512$ & $\geq 512$ & $\geq 512$ \\
\hline Tobramycin & & $<0.5$ & $<0.5$ & $<0.5$ & $<0.5$ \\
\hline
\end{tabular}

It has been shown that the growth media play an important role in the outcome of bacterial susceptibility to different charged peptides. Antimicrobial assays were performed in MHB cation-adjusted medium, a complex growth medium [39], and also in the less complex medium TSB [21]. In TSB we achieved approximately equal susceptibility results, uniform growth, and less variation in the repeated independent experiments. Unexpectedly, in both sets of experiments we noticed that at high concentrations the active compounds lost their ability to inhibit the growth of the microorganism. In particular, in the MHB-II medium, compound 1 lost its activity at concentrations higher than $8 \mu \mathrm{g} / \mathrm{mL}$, compounds 10, 15, 27, and 32 at concentrations higher than $32 \mu \mathrm{g} / \mathrm{mL}$, and compound 33 at concentrations higher than $16 \mu \mathrm{g} / \mathrm{mL}$. A similar behaviour for all the compounds was observed in the TSB medium. These results could be explained, considering a self-aggregation process of the tested compounds in the solvent system.

In the MHB-II medium, the MICs of tested compounds ranged from 2 to $256 \mu \mathrm{g} / \mathrm{mL}$. The majority of compounds showed detectable antimicrobial activity in the MIC range of $2-16 \mu \mathrm{g} / \mathrm{mL}$. The removal of the double bond (compound 10; MIC $4 \mu \mathrm{g} / \mathrm{mL}$ ), as well as the reduction of the double bond (compounds 33; MIC $2 \mu \mathrm{g} / \mathrm{mL}$ ) and the replacement with the triple bond (compound 32; MIC $4 \mu \mathrm{g} / \mathrm{mL}$ ), gave compounds which maintained a 
significant activity. Conversely, the replacement of the double bond with an amide group (compound 15) was deleterious (MIC $16 \mu \mathrm{g} / \mathrm{mL}$ ). Also, the replacement of ring A with a catechol was not successful in terms of activity, as compound 27 had a MIC of $16 \mu \mathrm{g} / \mathrm{mL}$. Compound 35, obtained by opening the benzofuran system, showed a very high MIC $(256 \mu \mathrm{g} / \mathrm{mL})$. This result confirmed that the heterocyclic ring plays an essential role for antimicrobial activity.

\section{Materials and Methods}

Synthesis. All chemicals used were of analytical grade. Procedures for the synthesis and characterization data for the various derivatives and intermediates are detailed in the Supplementary Materials.

Determination of minimum inhibition concentration (MIC) and minimum bactericidal concentration (MBC). The minimum inhibition concentration (MIC) of compounds was determined for S. aureus ATCC29213. The concentration range of the compounds were $0.25-512 \mu \mathrm{g} / \mathrm{mL}$. Tobramycin (T2503, TCI Europe N.V) was used as a control with a concentration range of $0.5-64 \mu \mathrm{g} / \mathrm{mL}$. One colony of $S$. aureus was inoculated in $5 \mathrm{~mL}$ growth media and incubated overnight in a water bath at $37^{\circ} \mathrm{C}, 180 \mathrm{rmp}$. Three biological replicas were used. The overnight cultures were diluted 1:50 and grown to exponential phase at OD600 0.4, either in MHB-II and in TSB. The bacterial culture was diluted 1:500 and transferred to a microdilution plate together with the compounds. The plate was then sealed and incubated overnight at $37^{\circ} \mathrm{C}$. After incubation, the plates were examined for microbial growth. A CFU assay was performed to estimate the final concentration of the 1:500 diluted culture. The expected concentration range was $2 \times 10^{5}-8 \times 10^{5} \mathrm{CFU} / \mathrm{mL}$. The results were obtained $24 \mathrm{~h}$ after incubation. To determine the MBC, $10 \mu \mathrm{L}$ of each compound concentration from the MIC, was transferred to LB (L3022 Sigma Aldrich) agar plates. The plates were incubated overnight at $37^{\circ} \mathrm{C}$. After incubation, the concentration at which no visible microbial growth was found was considered as the MBC.

\section{Conclusions}

The resveratrol dimer dehydro- $\delta$-viniferin, containing a benzofuran core, has been identified as a promising antimicrobial compound. As part of the research for new antimicrobials, our recent interest has been directed to the synthesis of new dehydro- $\delta$-viniferin analogues, to gain insights into the structural determinants for their activity. We investigated various protocols to access stilbenoid-derived 2,3-diaryl-5-substituted benzofurans, evidencing critical steps such as the demethylation of phenolic groups. Following these strategies, we prepared a focused collection of analogues, which were tested to evaluate their antimicrobial activity. Because of the modular nature of the synthetic approaches, ready access to diversity-oriented libraries of stilbenoid derived-benzofurans could be available.

Our study has evidenced that the styryl moiety, appended at $\mathrm{C} 5$ of the benzofuran ring, can be modified without affecting the antimicrobial activity of the compounds. Notably, the removal of the double bond (compound 10) andits conversion into a rigid linear triple bond (compound 32), or into a more flexible saturated chain (compound 33), gave compounds which were still endowed with significant antimicrobial activity. In this context, the simplified analogue $\mathbf{1 0}$ could represent a promising model compound for further development and investigation.

Supplementary Materials: The following are available online. Synthesis and characterization of compounds 1, 10, 15, 27, 32, 33, 35 [40,41].

Author Contributions: Conceptualization, A.P. and S.D.; methodology, L.M.M., C.P., G.C., L.M. and K.J.P.; investigation, L.M.M., C.P., G.C., L.M. and K.J.P.; resources, A.P., S.D. and K.A.K.; data curation, L.M.M., C.P., G.C., L.M. and K.J.P.; writing—original draft preparation, S.D., A.P. and K.A.K.; writing-review and editing, all authors. All authors have read and agreed to the published version of the manuscript.

Funding: This research received no external funding. 
Institutional Review Board Statement: Not applicable.

Informed Consent Statement: Not applicable.

Data Availability Statement: Not applicable.

Acknowledgments: This work was financially supported by “Transition Grant 2015-2017-Linea 1A" of the University of Milan. The work of Giorgia Catinella has been partially funded by Fondazione F.lli Confalonieri (Ph.D. Scholarship).

Conflicts of Interest: The authors declare no conflict of interest.

Sample Availability: Samples of the compounds 1, 10, 15, 27, 32, 33, 35 are available from the authors.

\section{References}

1. Keylor, M.H.; Matsuura, B.S.; Stephenson, C.R.J. Chemistry and Biology of Resveratrol-Derived Natural Products. Chem. Rev. 2015, 115, 8976-9027. [CrossRef] [PubMed]

2. Mattio, L.M.; Catinella, G.; Dallavalle, S.; Pinto, A. Stilbenoids: A natural arsenal against Bacterial pathogens. Antibiotics 2020, 9, 336. [CrossRef]

3. Pecyna, P.; Wargula, J.; Murias, M.; Kucinska, M. More than resveratrol: New insights into stilbene-based compounds. Biomolecules 2020, 10, 1111. [CrossRef] [PubMed]

4. Weiskirchen, S.; Weiskirchen, R. Resveratrol: How Much Wine Do You Have to Drink to Stay Healthy? Adv. Nutr. An Int. Rev. J. 2016, 7, 706-718. [CrossRef] [PubMed]

5. Lindgren, A.E.G.; Öberg, C.T.; Hillgren, J.M.; Elofsson, M. Total synthesis of the resveratrol oligomers ( \pm )-Ampelopsin B and ( \pm - $\sigma$-Viniferin. Eur. J. Org. Chem. 2016, 2016, 426-429. [CrossRef]

6. Vo, D.D.; Elofsson, M. Total Synthesis of Viniferifuran, Resveratrol-Piceatannol Hybrid, Anigopreissin A and AnaloguesInvestigation of Demethylation Strategies. Adv. Synth. Catal. 2016, 358, 4085-4092. [CrossRef] [PubMed]

7. Snyder, S.A.; Breazzano, S.P.; Ross, A.G.; Lin, Y.; Zografos, A.L. Total synthesis of diverse carbogenic complexity within the resveratrol class from a common building block. J. Am. Chem. Soc. 2009, 131, 1753-1765. [CrossRef]

8. Romero, K.J.; Keylor, M.H.; Griesser, M.; Zhu, X.; Strobel, E.J.; Pratt, D.A.; Stephenson, C.R.J. Synthesis of Vitisins A and D Enabled by a Persistent Radical Equilibrium. J. Am. Chem. Soc. 2020, 142, 6499-6504. [CrossRef]

9. Keylor, M.H.; Matsuura, B.S.; Griesser, M.; Chauvin, J.P.R.; Harding, R.A.; Kirillova, M.S.; Zhu, X.; Fischer, O.J.; Pratt, D.A.; Stephenson, C.R.J. Synthesis of resveratrol tetramers via a stereoconvergent radical equilibrium. Science 2016, 354, 1260-1265. [CrossRef] [PubMed]

10. Krzyzanowski, A.; Saleeb, M.; Elofsson, M. Synthesis of Indole-, Benzo[b]thiophene-, and Benzo[b]selenophene-Based Analogues of the Resveratrol Dimers Viniferifuran and ( \pm )-Dehydroampelopsin B. Org. Lett. 2018, 20, 6650-6654. [CrossRef]

11. Saleeb, M.; Mojica, S.; Eriksson, A.U.; Andersson, C.D.; Gylfe, Å.; Elofsson, M. Natural product inspired library synthesisIdentification of 2,3-diarylbenzofuran and 2,3-dihydrobenzofuran based inhibitors of Chlamydia trachomatis. Eur. J. Med. Chem. 2018, 143, 1077-1089. [CrossRef]

12. Chen, D.Y.K.; Kang, Q.; Wu, T.R. Modular synthesis of polyphenolic benzofurans, and application in the total synthesis of malibatol A and shoreaphenol. Molecules 2010, 15, 5909-5927. [CrossRef] [PubMed]

13. Liu, J.T.; Do, T.J.; Simmons, C.J.; Lynch, J.C.; Gu, W.; Ma, Z.X.; Xu, W.; Tang, W. Total synthesis of diptoindonesin G and its analogues as selective modulators of estrogen receptors. Org. Biomol. Chem. 2016, 14, 8927-8930. [CrossRef] [PubMed]

14. Vo, D.D.; Elofsson, M. Synthesis of 4-Formyl-2-arylbenzofuran Derivatives by $\mathrm{PdCl}(\mathrm{C} 3 \mathrm{H} 5) \mathrm{dppb}$-Catalyzed Tandem Sonogashira Coupling-Cyclization under Microwave Irradiation-Application to the Synthesis of Viniferifuran Analogues. ChemistrySelect 2017, 2, 6245-6248. [CrossRef]

15. Khanam, H. Shamsuzzaman Bioactive Benzofuran derivatives: A review. Eur. J. Med. Chem. 2015, 97, 483-504. [CrossRef] [PubMed]

16. Naik, R.; Harmalkar, D.S.; Xu, X.; Jang, K.; Lee, K. Bioactive benzofuran derivatives: Moracins A-Z in medicinal chemistry. Eur. J. Med. Chem. 2015, 90, 379-393. [CrossRef] [PubMed]

17. Chand, K.; Hiremathad, A.; Singh, M.; Santos, M.A.; Keri, R.S. A review on antioxidant potential of bioactive heterocycle benzofuran: Natural and synthetic derivatives. Pharmacol. Rep. 2017, 69, 281-295. [CrossRef] [PubMed]

18. Miao, Y.H.; Hu, Y.H.; Yang, J.; Liu, T.; Sun, J.; Wang, X.J. Natural source, bioactivity and synthesis of benzofuran derivatives. RSC Adv. 2019, 9, 27510-27540. [CrossRef]

19. Hiremathad, A.; Patil, M.R.; Chethana, K.R.; Chand, K.; Santos, M.A.; Keri, R.S. Benzofuran: An emerging scaffold for antimicrobial agents. RSC Adv. 2015, 5, 96809-96828. [CrossRef]

20. Elsherif, M.A.; Hassan, A.S.; Moustafa, G.O.; Awad, H.M.; Morsy, N.M. Antimicrobial evaluation and molecular properties prediction of pyrazolines incorporating benzofuran and pyrazole moieties. J. Appl. Pharm. Sci. 2020, 10, 37-43. [CrossRef]

21. Mattio, L.M.; Dallavalle, S.; Musso, L.; Filardi, R.; Franzetti, L.; Pellegrino, L.; D’Incecco, P.; Mora, D.; Pinto, A.; Arioli, S. Antimicrobial activity of resveratrol-derived monomers and dimers against foodborne pathogens. Sci. Rep. 2019, 9, 1-13. [CrossRef] 
22. Catinella, G.; Mattio, L.M.; Musso, L.; Arioli, S.; Mora, D.; Beretta, G.L.; Za, N.; Pinto, A.; Dallavalle, S. Structural Requirements of Benzofuran Derivatives Dehydro- $\delta$-and Dehydro- $\varepsilon$-Viniferin for Antimicrobial Activity Against the Foodborne Pathogen Listeria monocytogenes. Int. J. Mol. Sci. 2020, 21, 2168. [CrossRef] [PubMed]

23. Lamaa, D.; Hauguel, C.; Lin, H.-P.; Messe, E.; Gandon, V.; Alami, M.; Hamze, A. Sequential One-Pot Synthesis of 3-Arylbenzofurans from N-Tosylhydrazones and Bromophenol Derivatives. J. Org. Chem. 2020, 85, 13664-13673. [CrossRef] [PubMed]

24. Basu, P.; Satam, N.; Namboothiri, I.N.N. Synthesis of indenofurans, benzofurans and spiro-lactones: Via Hauser-Kraus annulation involving 1,6-addition of phthalide to quinone methides. Org. Biomol. Chem. 2020, 18, 5677-5687. [CrossRef] [PubMed]

25. Das, P.; Maity, S.; Ghosh, P.; Dutta, A.; Das, S. Condensation of ninhydrin with phenols: Regioselective formation of diverse organic scaffolds and crystal structure studies. J. Mol. Struct. 2020, 1202, 127260. [CrossRef]

26. Singh, G.; Goswami, P.; Sharma, S.; Anand, R.V. A One-Pot Approach to 2,3-Diarylbenzo[b]furans through N-Heterocyclic Carbene-Catalyzed 1,6-Conjugate Addition Followed by Acid Mediated Dehydrative Annulation. J. Org. Chem. 2018, 83, 56. [CrossRef] [PubMed]

27. Fan, X.; He, H.; Li, J.; Luo, G.; Zheng, Y.; Zhou, J.K.; He, J.; Pu, W.; Zhao, Y. Discovery of 4,6-bis(benzyloxy)-3-phenylbenzofuran as a novel Pin1 inhibitor to suppress hepatocellular carcinoma via upregulating microRNA biogenesis. Bioorg. Med. Chem. 2019, 27, 2235-2244. [CrossRef] [PubMed]

28. Liou, Y.C.; Karanam, P.; Jang, Y.J.; Lin, W. Synthesis of Functionalized Benzofurans from para-Quinone Methides via Phospha-1,6Addition/ O-Acylation/Wittig Pathway. Org. Lett. 2019, 21, 8008-8012. [CrossRef] [PubMed]

29. Arcadi, A.; Cacchi, S.; Del Rosario, M.; Fabrizi, G.; Marinelli, F. Palladium-catalyzed reaction of o-ethynylphenols, o-((trimethylsilyl)ethynyl)phenyl acetates, and o-alkynylphenols with unsaturated triflates or halides: A route to 2-substituted-, 2,3-disubstituted-, and 2-substituted-3-acylbenzo[b]furans. J. Org. Chem. 1996, 61, 9280-9288. [CrossRef]

30. Markina, N.A.; Chen, Y.; Larock, R.C. Efficient microwave-assisted one-pot three-component synthesis of 2,3-disubstituted benzofurans under Sonogashira conditions. Tetrahedron 2013, 69, 2701-2713. [CrossRef] [PubMed]

31. St. John, S.E.; Jensen, K.C.; Kang, S.; Chen, Y.; Calamini, B.; Mesecar, A.D.; Lipton, M.A. Design, synthesis, biological and structural evaluation of functionalized resveratrol analogues as inhibitors of quinone reductase 2. Bioorganic Med. Chem. 2013, 21, 6022-6037. [CrossRef]

32. Stockdale, D.P.; Titunick, M.B.; Biegler, J.M.; Reed, J.L.; Hartung, A.M.; Wiemer, D.F.; McLaughlin, P.J.; Neighbors, J.D. Selective opioid growth factor receptor antagonists based on a stilbene isostere. Bioorganic Med. Chem. 2017, 25, 4464-4474. [CrossRef] [PubMed]

33. Stockdale, D.P.; Beutler, J.A.; Wiemer, D.F. Synthesis of amide isosteres of schweinfurthin-based stilbenes. Bioorganic Med. Chem. 2017, 25, 5483-5489. [CrossRef] [PubMed]

34. Li, X.C.; Ferreira, D. Stereoselective cyclization of stilbene derived carbocations. Tetrahedron 2003, 59, 1501-1507. [CrossRef]

35. Velu, S.; Thomas, N.; Weber, J.F. Strategies and methods for the syntheses of natural oligomeric stilbenoids and analogues. Curr. Org. Chem. 2012, 16, 605-662. [CrossRef]

36. Schmidt, B.; Riemer, M.; Karras, M. 2,2'-Biphenols Via Protecting Group-Free Thermal or Microwave-Accelerated Suzuki-Miyaura Coupling in Water. J. Org. Chem. 2013, 78, 8680-8688. [CrossRef] [PubMed]

37. Gibtner, T.; Hampel, F.; Gisselbrecht, J.P.; Hirsch, A. End-cap stabilized oligoynes: Model compounds for the linear sp carbon allotrope carbyne. Chem. A Eur. J. 2002, 8, 408-432. [CrossRef]

38. Yue, F.; Lu, F.; Regner, M.; Sun, R.; Ralph, J. Lignin-Derived Thioacidolysis Dimers: Reevaluation, New Products, Authentication, and Quantification. ChemSusChem 2017, 10, 830-835. [CrossRef]

39. Wiegand, I.; Hilpert, K.; Hancock, R.E.W. Agar and broth dilution methods to determine the minimal inhibitory concentration (MIC) of antimicrobial substances. Nat. Protoc. 2008, 3, 163-175. [CrossRef]

40. Teng, B.H.; Zhu, Q.B.; Fan, Y.Y.; Yao, C.S. Total synthesis of the active resveratrol dimer dehydro- $\delta$-viniferin. J. Asian. Nat. Prod. Res. 2020, 22, 947-955. [CrossRef]

41. Hoshino, J.; Park, E.J.; Kondratyuk, T.P.; Marler, L.; Pezzuto, J.M.; van Breemen, R.B.; Mo, S.; Li, Y.; Cushman, M. Selective Synthesis and Biological Evaluation of Sulfate-Conjugated Resveratrol Metabolites. J. Med. Chem. 2010, 53, 5033-5043. [CrossRef] [PubMed] 